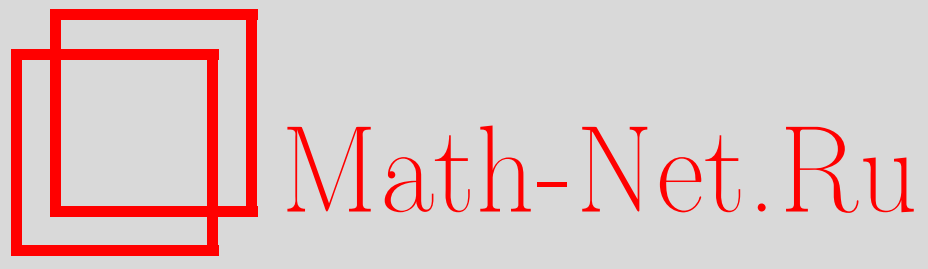

Информация о работе большого семинара кафедры теории вероятностей механико-математического факультета МГУ, Теория вероятн. и ее примен., 2001, том 46, выпуск 4, 821-823

DOI: https://doi.org/10.4213/tvp3833

Использование Общероссийского математического портала Math$\mathrm{Net.Ru}$ подразумевает, что вы прочитали и согласны с пользовательским соглашением

http://www . mathnet.ru/rus/agreement

Параметры загрузки:

IP : 52.87 .193 .239

26 апреля 2023 г., 16:47:16

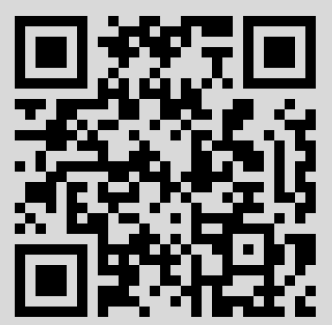




\section{ИНФОРМАЦИЯ О РАБОТЕ БОЛЬШОГО СЕМИНАРА КАФЕДРЫ ТЕОРИИ ВЕРОЯТНОСТЕЙ МЕХАНИКО-МАТЕМАТИЧЕСКОГО ФАКУЛЬТЕТА МГУ}

Семинар является продолжением научно-исследовательского семинара кафедры теории вероятностей под руководством А.Н. Колмогорова и Б. В. Гнеденко.

В настоящее время руководителем семинара является чл.-корр. РАН профессор А. Н. Ширяев.

Заседания семинара проходят по средам с 16 ч. 20 мин. в аудитории 16-24 главного здания МГУ. С текущей информацией о работе семинара можно ознакомиться на кафедре теории вероятностей (тел. 939-14-03).

Информация о будущих докладах рассылается по электронной почте. Заявку на ее регулярное получение можно сделать на кафедре теории вероятностей ученому секретарю семинара (e-mail: urusov@mech.math.msu.su).

С мая 2000 г. предзащиты кандидатских диссертаций студентов кафедры теории вероятностей проходят на большом семинаре.

Ниже приводится полный список докладов за период с сентября 2000 г. по октябрь 2001 г.

\section{Осенний семестр 2000 г.}

6 сентября - Я. Г. Синай (Принстон, США). Единственность стачионарного распределения для двумерного уравнения Навье-Стокса со случайной силой.

13 сентября - А.И. Комеч (Москва). Двухтемпературная задача для волнового уравнения.

20 сентября - Ю. А. Рылов (Москва). Динамическая концепиия статистического описания.

27 сентября - А.Н. Ширяев (Москва). Алгебра кумулянтных прочессов для семимартингалов и конструкиия (по Эиеру) мартингальньх мер.

4 октября - А. И. Нейштадт (Москва), Т. В. Селезнева (Москва), В. Н. Тутубалин (Москва), Е.Г. Угер (Москва). Уточнение «теории спекулячии» Л. Башелье.

11 октября -- А.Н. Ширяев (Москва). Урок стохастического исчисления (на примере получения стохастических интегральных представлений для частичных максимумов от броуновского движения).

18 октября - Д. Д. Соколов (Москва). Геодезические на многообразиях со случайной кривизной.

25 октября - заседание, посвященное памяти доктора физико-математических наук профессора Льва Дмитриевича Мешалкина.

8 ноября - Ю. Линке (Новосибирск). Оченивание для дробно-линейной регресcuu.

15 ноября - В. И. Питербарг (Москва), М. В. Козлов (Москва), А. М. Козлов (Москва). Большие скачки случайного блуждания.

22 ноября - П. А. Виленкин (Москва). Исследования по теории информации и комбинаторной теории кодирования (предзащита кандидатской диссертации). 
29 ноября - А.И. Кириллов (Москва). Об одном свойстве решений бесконечномерньх стохастических дифференииальньх уравнений.

6 декабря - А.Н. Фролов (Санкт-Петербург). Предельные теоремы для приращений сумм независимых случайных величин.

13 декабря - Д. В. Хмелев (Москва). Теоремы о глобальной устойчивости больших транспортных сетей (предзащита кандидатской диссертации).

20 декабря - А.П. Коростелев (Москва). Последовательное планирование эксперимента в задачах непараметрической регрессии.

Весенний семестр 2001 г.

14 февраля - А.Н. Ширяев (Москва). Задача о разладке для прочесса Пуассона.

21 февраля - Р.А. Минлос (Москва). Случайные блуждания в случайной динамической среде.

28 февраля - Ю.Ю. Бахтин (Москва). Доклад-представление кандидатской диссертации: Предельные теоремь для стохастических решений уравнения Бюргерса. Научный руководитель: профессор А. В. Булинский.

7 марта - Г. М. Молчан (Москва). О максимуме фрактального броуновского движения.

14 марта - В.В. Сенатов (Москва). Асимптотические разложения в чентральной предельной теореме с использованием моментов Чебышёва-Эрмита.

21 марта - А. Е. Кондратенко (Москва). Доклад-представление кандидатской диссертации: Точность аппроксимачии сверток распределений асимптотическими разложениями. Научный руководитель: профессор В.В.Сенатов.

28 марта - Н. Д. Введенская (Москва). Модели систем обслуживания с динамической марирутизачией.

4 апреля - А.Е. Микушева (Москва). Доклад-представление кандидатской диссертации: Сходимость вполне и предельные теоремы в схеме серий. Научный руководитель: профессор А. В. Булинский.

18 апреля - А. Н. Тихомиров (Сыктывкар). О скорости сходимости спектра случайных матрич $x$ полукруговому закону и закону Марченко-Пастура.

25 апреля - Т. А. Романова (Москва). Доклад-представление кандидатской диссертации: Математическое моделирование некоторых методов проверки статистических гипотез, основанньх на теории больиих уклонений. Научные руководители: профессор Ю.Н. Тюрин и профессор В.И. Питербарг; А.Н. Ладнева (Москва). Доклад-представление кандидатской диссертации: Асимптотические методы исследования вероятностей нескольких одновременных экстремумов гауссовских случайных прочессов и полей. Научный руководитель: профессор В. И. Питербарг.

16 мая - А. А. Замятин, А. А. Ямбарцев (Москва). Динамика взаимодействуюиих случайных слов.

Осенний семестр 2001 г. (по октябрь включительно).

5 сентября - Я. Г. Синай (Принстон). Проблема $3 x+1$.

12 сентября - А. С. Черный (Москва). О сильной и слабой единственности для стохастических дифференчиальньх уравнений.

19 сентября - П.В. Гапеев (Москва). Доклад-представление кандидатской диссертации: Байесовские и вариачионные задачи последовательного анализа. Научный руководитель: профессор А.Н. Ширяев; А. А. Русаков (Москва). Докладпредставление кандидатской диссертации: Выбросы векторных гауссовских прочессов. Научный руководитель: профессор Ю. К. Беляев.

26 сентября - А.Н. Ширяев (Москва). Стохастическая экспонента, стохастический погарифм, кумулянты, замена меры с помощью преобразования Эшера. 
3 октября - В.Н. Тутубалин, Е.Г. Угер (Москва). Оченка возможности внедрения «русского опииона» на фондовом рынке.

10 октября - Ф.Н. Еникеева (Москва). Доклад-представление кандидатской диссертации: Асимптотически минимаксное оченивание в задаче Виксела. Научные руководители: профессор В. В. Калашников и профессор Г. К. Голубев; А. В. Топчий (Москва). Доклад-представление кандидатской диссертации: Многомерный непараметрический анализ линейных моделей. Научный руководитель: профессор Ю. Н. Тюрин.

17 октября - А. С. Черный, А.Н. ІПиряев (Москва). Принцип инвариантности для горизонтально-вертикального блуждания на плоскости.

24 октября - Разбор задач студенческой олимпиады и вручение призов.

31 октября - Заседание, посвященное памяти доктора физико-математических наук профессора Александра Дмитриевича Соловьева.

Координаторы семинара: проф. Е. В. Булинская, проф. В. И. Питербарг, проф. А. А. Гушин

Уч. секр.: А. С. Черный, М. А. Урусов

\section{ИНФОРМАЦИЯ О СТУДЕНЧЕСКОЙ ОЛИМПИАДЕ ПО ТЕОРИИ ВЕРОЯТНОСТЕЙ}

Кафедра теории вероятностей механико-математического факультета Московского государственного университета им. М. В. Ломоносова при поддержке Франкорусского центра им. А. М. Ляпунова провела первую «Колмогоровскую студенческую олимпиаду по теории вероятностей».

В оргкомитет по проведению олимпиады вошли заведующий кафедрой теории вероятностей член-корреспондент РАН, профессор А.Н. Ширяев (председатель оргкомитета), ассистенты кафедры теории вероятностей П. А. Виленкин и А. С. Черный, аспиранты кафедры теории вероятностей Ю. А. Кузнецов и М. А. Урусов.

Олимпиада была проведена 20 октября 2001 г. (продолжительность - 4 часа). Оргкомитет констатирует, что в олимпиаде приняли участие 23 студента III-V курсов механико-математического факультета и факультета ВМиК.

Задачи олимпиады. (Число в скобках после номера задачи указывает количество студентов, решивших данную задачу.)

Задача 1. (18) Пусть $X=\left(X^{1}, X^{2}\right)$ - двумерная случайная величина, являюшаяся непрерывной, т.е. $\mathbf{P}\{X=x\}=0$ для любого $x \in \mathbf{R}^{2}$. Верно ли, что ее функция распределения $F\left(x^{1}, x^{2}\right)=\mathbf{P}\left\{X^{1} \leqslant x^{1}, X^{2} \leqslant x^{2}\right\}$ непрерывна?

Задача 2. (9) Пусть $\left(X_{n}\right)_{n=1}^{\infty}$ - последовательность независимьх случайных величин, сходящаяся по вероятности (при $n \rightarrow \infty$ ) к случайной величине $X$. Доказать, что $X$ является вырожденной случайной величиной, т.е. существует $x \in \mathbf{R}$ такое, что $X=x$ п.н.

Задача 3. (7) Привести пример четырех зависимьх случайных событий $A_{1}, A_{2}, A_{3}, A_{4}$ таких, что любые три из них взаимно независимы.

Задача 4. а) (9) Пусть $X, Y$ - случайные величины с $\mathbf{E} X^{2}<\infty, \mathbf{E} Y^{2}<\infty$ такие, что $\mathbf{E}(X \mid Y)=\dot{Y}, \mathbf{E}(Y \mid X)=X$. Доказать, что $X=Y$ п.н.

б) (0) Пусть $X, Y$ - случайные величины с $\mathbf{E}|X|<\infty, \mathbf{E}|Y|<\infty$ такие, что $\mathbf{E}(X \mid Y) \geqslant Y, \mathbf{E}(Y \mid X) \geqslant X$. Доказать, что $X=Y$ п.н. 